臨床 著明な骨变化を伴ら偽性副甲状腺機能低下症 II 型 に抗てんかん薬による甲状腺機能低下症が合併した 1 症例

\author{
群馬大学医学部第二内科 \\ 吉田忠義 矢島日出登 鎗田 宏 福田 丈了
}

\title{
PSEUDOHYPOPARATHYROIDISM TYPE II WITH MARKED VERTEBRAL DEFORMITY AND HYPOTHYROIDISM INDUCED BY ANTICONVULSANTS. A CASE REPORT.
}

Tadayoshi YoshidA, MD, Hideto YaJIMA, MD, Hiroshi YARITA, MD and Takesatoru FukUdA, MD

The Second Department of Internal Medicine Gunma University School of Medicine, Maebashi.

概要 低カルシウム血症，高燃血症を呈した35才男性に，Ellsworth-Howard試験を行ない， Dreznerら"1)提唱した偽性副甲状腺機能低下症II型（PHPII型）と診断し得た症例を報告す る.本例には次のような特徵があつた（1）意識消失を伴う㾏卛発作一てんかんが起きたが， PHPII 型で意識消失発作が起こること江希といわれている. (2) Albright's osteodystrophyの 身体的特徽が比較的軽钽であり，PHPにみられる他の臨床症状，徽候も比較的少なかつ大（3） 下肢の浮腫が入院の契機となり，本症診断の糸口となつた。浮腫は $\mathrm{T}_{3}, \mathrm{~T}_{4}$ などの甲状腺機能検 查から，甲状腺機能低下症が存在することが判明し，このために起こつたと考光られた。さら に抗てんかん薬（ジフェニールヒダントイン，カルマバゼピン）がT $\mathrm{T}_{3}, \mathrm{~T}_{4}$ の低下をるたらした と推測された.（4）Ellsworth-Howard試験で尿中cAMPの增量があつたが，尿中燐の排泄増加 はなかつた。これによりDreznerらのPHPII型と㟝断した。（5）骨にX線像上著明な変形があ り，抗てんかん薬に上る骨軟化症とPHPII型がその原因と考克られた。（6）血清25(OH） $\mathrm{D}_{3}$ ， $1-25(\mathrm{OH})_{2} \mathrm{D}_{3}$ の低下があつたが，前者は抗てんかん薬による影響と，後者はPHPII型との関 連が考えられた。

\section{はじめに}

偽性副甲状腺機能低下症 (PHP) はDreznerら" によれば, Ellsworth-Howard試験（EH試験）に よる尿中cAMPと燐の排泄によつて, I 型(cAMP と燐の尿中排泄増加のないるの）とII型（cAMP の排泄増加はあるが，燐排泄増加のないるの）に 分けている。また，最近に和ける副甲状腺ホルモ ン (PTH)，Vitamin D, N蛋白などについての知 見の集積により，本症についての従来の概念は変 わりつつあり, 本症はホルモン受容体異常症の代 表的疾患の一つともなつた

また通常のPHP と異なつて，PTHが腎には作 用しないが，骨に作用して骨炎を呈するPHPd報 告されている6)。すなわち本症に特いてはホルモ

\footnotetext{
[昭和57年10月 1 日受稿]
}

ンの作用機序の解明と共に，障害部位がより正確 になつて来たし，多彩な臨床像も指摘されるよう にななな。

私共は, 最近骨变化を伴うPHPII型に抗てんか 几薬服用による甲状腺機能低下症を合併する 1 症 例を経験したので，その臨床像と検㚗成績に文献 的考察を加えて報告する。このような異常な徵候 を呈したPHPII型は私共の調べた限りこれが初 めての本邦での報告である。

$$
\text { 症例 }
$$

症例：○良○雄, 35才, 男性。

主訴：下腿の浮腫, 㓐攣発作, 歩行障害.

既往歴：泗期正常出産で, 体重は3000g. 出生 後より両側の手に变形があつた。17才虫垂炎の手 術を受けた。

家族歴：4 人兄弟で皆健康である. 
現病歴：16才の時, 突然意識消失を伴う全身 性疰攣発作が起こつた。発作の頻度は, 初め 2 力 月に 1 度位であつたが, 1 カ月に数回同様の発作 が起こるようになつたため, 某院に通院，てんか んとの診断のもとに薬を服用していたが服薬が不 規則だつたため数年に 1 度くらい痉卛発作が起き た。昭和57年 3 月末，強直性痉卛発作が 1 力月に $2 \sim 3$ 度起こつたので, 某院脳外科に入院, ジフェ ニールヒダントイン，カルマバゼピン，バルプロ 酸などの抗てんかん薬投与を受けた。同年 4 月 11 日発作も扣さまつたので退院した。 4 月下旬下腿 に非陥凹性浮腫が出現したため，館林厚生病院内 科を受診し，利尿薬の投与を受けたが軽快せず，

5 月15日同院に入院，低カルシウム血症，低燐血 症， $\mathrm{T}_{3}, \mathrm{~T}_{4}$ の低下を指摘され精査のため当科に転 院した。

理学的所見：身長 $163 \mathrm{~cm}$, 体重 $60 \mathrm{~kg}$, 血圧 $124 / 80 \mathrm{mmHg}$, 脈拍 $60 /$ 分, 整, 意識は清明だが, 日本国首相の名前が判らず, $100-7$ の計算が出来 ない程知能は低い，盗椎側弯症あり．疾性歩行を 示す。両手指は動くが，II－V指とも尺骨側に屈 曲し, 精緻な運動は出来ない。負血, 黄疸なし. 瞳孔は正円同大で，対光反射は迅速．軽度の水平 性注視眼振あり。歯は全部抜けて，自分の歯はな い.甲状腺腫なし，胸部に異常なし，腹部はやや 膨隆するも肝脾腫なし，両足背および前怪骨部に 軽度の浮腫があつた。 Chvostek, Trousseau徵候 共になし．腱反射は左右ともやや下肢で立進し， アキレス腱反射の弛緩性達延があつた. Babinski, Chaddock反射陰性. 小脳機能, 知覚検査に異常は なかつた。

検査成績： 尿便に異常なし，末梢血液はへモ グロビン $12.4 \mathrm{~g} / \mathrm{dl}$, 赤血球 400 万 $/ \mathrm{cmm}$, ヘマトク リット $36.2 \%$, 白血球 $3900 / \mathrm{cmm}$, 血小板 9 万/ $\mathrm{cmm}$, 血液像に異常なし。TPHA(一). 血液生化 学検査では, 総蛋白 $7.4 \mathrm{~g} / \mathrm{dl}$, GOT 29, GPT 26 , LDH 573, alk-P-ase 308, LAP 84, $\gamma$ GTP 86, CPK 159(MM型94\%)，(いずれも IU/l). 酸フォ スファターゼ 3.9 KAU (正常 0.5 3.5). BUN $13 \mathrm{mg} / \mathrm{dl}$, クレアチニン $1.0 \mathrm{mg} / \mathrm{dl}$. Na $140, \mathrm{~K} 3.4$,
$\mathrm{Cl} 97, \mathrm{mEq} / l$. Ca $5.6 \sim 6.6 \mathrm{mg} / \mathrm{dl}, \mathrm{P} 6.0 \sim 7.8 \mathrm{mg} /$ $\mathrm{dl}, \mathrm{Mg} 2.1 \sim 2.3 \mathrm{mg} / \mathrm{dl}$. 総コレステロール 174 , 中 性脂肪 $76, \beta$ ポ蛋白 $314 \mathrm{mg} / \mathrm{dl}$. Alb 58.9, $\alpha_{1}$ gl 3. $0, \alpha_{2}$ gl 9.6, $\beta$ gl 18.4, $\gamma$ gl 9.9\%. IgG 1061, IgA 530, IgM 99mg/dl. ChE 5.4, TTT 0.7, ZTT 5.0, 尿酸 $4.4 \mathrm{mg} / \mathrm{dl}$. NEFA $0.21 \mathrm{mEq} / l$. ICG $9.8 \%$. ASLO 100 Todds U以下, CRP (-), RA (-). 血清鉄 139 , 血清銅 98 , UIBC $154 \mu \mathrm{g} / \mathrm{dl}$. 空腹時血 糖 $69 \mathrm{mg} / \mathrm{dl}$. 胸部 $\mathrm{X}$ 線像で右大動脈弓が認められ た。心電図には軽度のQT (QTc $=0.47 \mathrm{~s})$ の延長 があつた. HLAはA2, AW 33, BW 35, BW 44, CW 3であつた. Alk P-aseアイソザイムは 1 型 $4 \%, 2 \sim 3$ 型 $85 \%$ ( 2 と 3 の比は 5.5対 4.5)， 4 ～ 5 型 $11 \%$. 染色体， 46XY. PSP 25\%（15分), 68\% (120分). 手足のX線像で第IV中手骨, 第山・ IV中足骨の短縮が認められた。脊椎骨のX線像 (図 1)はいわゆるcodfish vertebraを呈し，全体に骨 陰影は淡影化していた. bone cystは認められなか

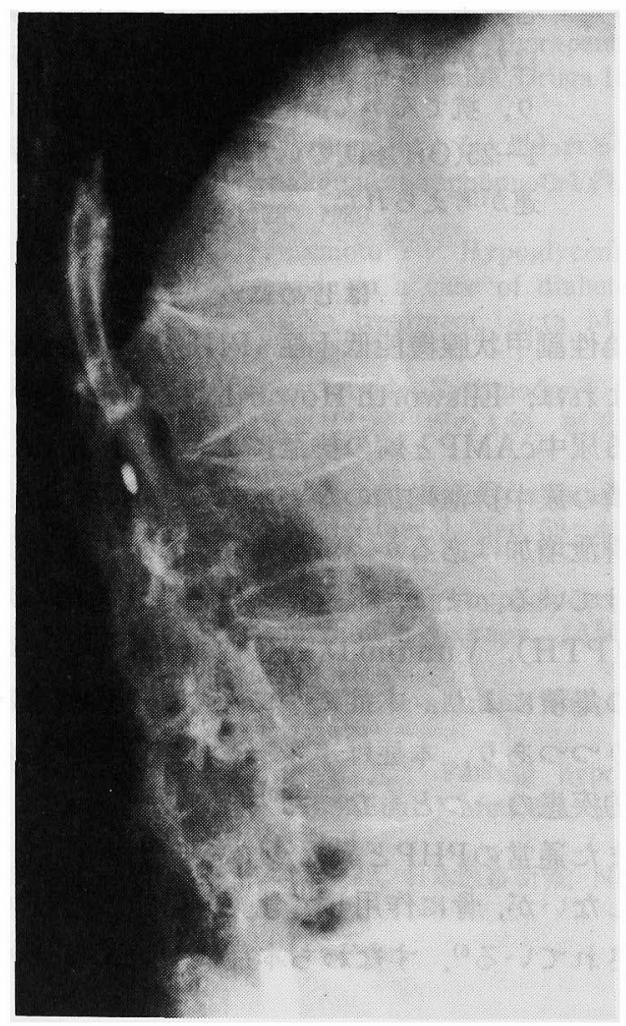

図 1 ，著明な脊椎骨の変形を示す。 


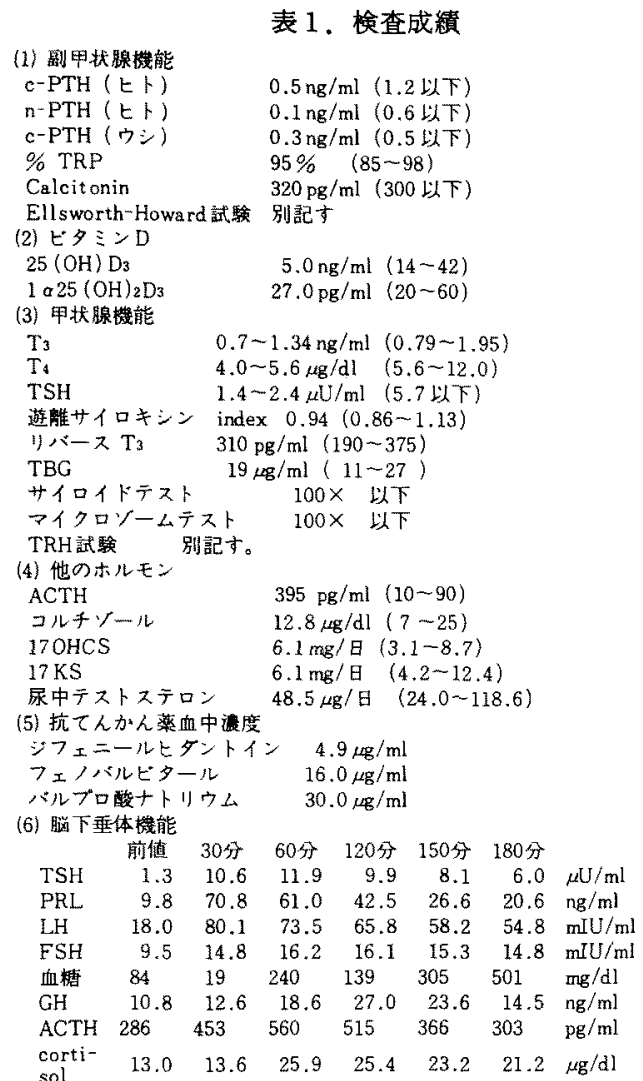

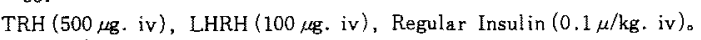
$\mathrm{PRL}=$ プロラクチン

Insulin 注射後低血楉発作を起こす。ブドウ糖静注す。

つた。大柦骨のX線像です骨陰影は全体に淡影化 し，骨膜下吸収の像が認められた，脳波では覚醒 時汎発性にslow $\alpha$ 波に高振幅の $\theta$ 波が混入し， 時々spikeないしspike and wave complex 出現 した。閃光刺激で著変なし，過呼吸で著明な徐波 出現，睡眠でspike括よびspike and wave complexが頻発した，WAISによるIQ（言語性16，動 作性22）は60以下であつた。副甲状腺機能検查, ビタミン $\mathrm{D}_{3}$ 抢よび抗てんかん薬の血中濃度, 甲状 腺機能検查や他のホルモン検査の成績を表 1 に示 した。

$\mathrm{EH}$ 試験の結果を図 2 に示した。

以上より骨変化を伴 5 PHP II 型に甲状腺機能 低下症が合併した症例と診断した。

入院後の経過：甲状腺機能検査の経過は表 2 に示したごとく変化した，抗てんかん薬はヒダン

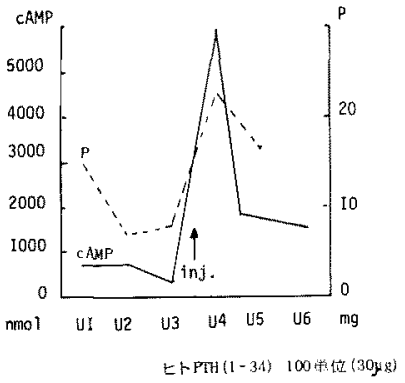

因 2. Ellsworth-Howard試験

cAMP の $\mathrm{U}_{4} / \mathrm{U}_{3}$ 比は25倍, $\mathrm{U}_{4}-\mathrm{U}_{3}$ は $1.0 \mu \mathrm{mol} / \mathrm{h}$ 以 上. $\mathrm{P}$ は $\left(\mathrm{U}_{4}+\mathrm{U}_{5}\right)-\left(\mathrm{U}_{3}+\mathrm{U}_{2}\right)=26.1 \mathrm{mg} / 2 \mathrm{~h}$. 従つて cAMPは反応するが，Pは反応しない．

表 2.甲状腺機能の経時的変化

\begin{tabular}{|c|c|c|c|c|c|c|}
\hline & 5月17日 & 5月31日 & 6 月 15 日 & $6922 日$ & 9月8日 & \\
\hline $\mathrm{T}_{3}$ & 0.7 & 1.1 & 1.06 & 0.89 & 1.00 & $\mathrm{ng} / \mathrm{m}]$ \\
\hline$T_{4}$ & 4.2 & 4.0 & 5.3 & 5.6 & 4.8 & $\mu \mathrm{g} / \mathrm{ml}$ \\
\hline TSH & 2.4 & 2.4 & 1.4 & 2.0 & 1.25 以下 & $\mu U / \mathrm{m}$ \\
\hline
\end{tabular}

トールF 12鋄/日，カルマバゼピン $600 \mathrm{mg} /$ 日,バル プロ酸 $1200 \mathrm{mg} /$ 日を服用していたが，6月15日以 後，ヒダントールFを9 錠/日とバルプロ酸600 $\mathrm{mg} /$ 日に減量服用している。なお下肢の浮畽は漸 次減少し，9月10日現在全く消失した。 $1(\mathrm{OH})$ $\mathrm{D}_{3}$ を経口投与し，現在経過観察中である。

\section{考案}

本例は低カルシウム血症，高燐血症，中手骨の 短縮, 痉攣発作, 菊芽異常などの臨床症状と $\mathrm{EH}$ 試 験による尿中cAMPの排泄増加，同燐排泄量の不 変なことからPHPII型と診断した，PHPは現在 均一な疾患とは考党られて括らず，多くの疾患に 細分されようとしている.Dreznerら"ね，EH試験 による尿中cAMPと燐の反応からPHPを 2 型に 分け, Farbel 出性, PTH, N蛋白, Adenyl cyclase 系の関係を明らかにした。なた Frameら6)は， PTHの藏器 (腎, 骨)の反応によつてPHPを 3 型 に分類した．本例はDreznerら PHPII型に当るし，Frameら の分類に従点ば，骨 炎を伴つているからPHP type Iに当る。すなわち 本例は骨炎を伴うPHPII型ということになり，私 共の調べた限りこのような症例の報告はない. 
PHPの診断にはEH試験と immunoreactive PTH (iPTH) の測定が重要である. Dreznerら" がEH試験によりPHPを 2 型に分類したことは既 に述べた。 PHPの診断は, iPTHを測定して,その 高值を証明すれば確実である。プロホルモンなど の問題, 測定施設に括ける測定値の変動の問題, $\mathrm{n}$ 末端や $\mathrm{c}$ 末端の測定法の問題などがあり，現在 その測定だけで副甲状腺低下症の診断を断定する 段階には至つていないこれは厚生省研究班の PHPの診断基準7るみても，PHP值の高いことな いし正常なことを診断基準としていることからも らかがわれる。本例ではiPTH（ヒト，ウシ)は正 常であつた。 な扗土屋ら ${ }^{8)}$ のPHPII型の報告では, 1 例のPTHは低値を示している。

本例の臨床像と従来報告されている PHP, PHPII型のそれを比較検討してみる。本例の初発 症状は全身性疹彎発作で, 意識消失を伴つていた。 㾏變発作はPHPI，II型でそれぞれ53，40\%起こる といわれているが, PHPII型では意識消失例は記 載されていない9．疼攣発作一てんかん発症の機 序を考えれば，発作が強く長ければ当然意識障害 が起こると予測される。

本例で認められた臨床像は，知能低下(PHPで の出現率, $\left.53 \%{ }^{99}\right)$, 中手骨の短縮 $\left(67 \%{ }^{9)}\right)$, 荬芽 異常 $\left(60 \%^{9)}\right)$ などであり，テタ二ー $\left(71 \%^{91}\right)$, パ レステジー $\left(74 \%{ }^{9)}\right)$, 筋㾏卛 $\left(56 \%{ }^{9)}\right)$, 不随意運 動 $\left(22 \%{ }^{9)}\right)$, 肥満 $\left(58 \%{ }^{9)}\right)$, 短身長 $\left(66 \%{ }^{9)}\right)$, 円 形顔貌 $\left(81 \%^{9)}\right)$ ，皮下石灰化 $\left(36 \%{ }^{9)}\right)$ ，大脳基底 核石灰化 $\left(48 \%{ }^{10)}\right)$, 白内障 $\left(43 \%{ }^{9)}\right)$ など従来比較 的よく記載されている症状，徵候を欠いていた。 すなわち本例はAlbright's osteodystrophyといわ れる身体的特徵が比較的目立たない症例であつ た。一般にPHPII型の臨床像やカルシウム，燐な との検査成績はPHP I 型のそれより軽いといわ れているが，本例も意識障害を伴つたてんかん発 作以外例外ではなかつた。

本例の診断のきつかけになつた臨床症状は足背 の浮腫であつた。浮腫の原因を調べるため入院し たところ, 低カルシゥム, 高燐血症が指摘され, EH試験でPHPII型と診断が確定した例である.
本例は心臓, 腎臓, 肝臓に浮腫を来す程の異常が なく，下腿の静脈造影にも異常がなく $\mathrm{T}_{3}, \mathrm{~T}_{4}$ の低 下から甲状腺機能低下症が，原因として考えられ た。抗てんかん薬が甲状腺機能に影響を及活すと 報告されているが(1) 14), 臨床的に明らかな甲状腺 機能低下症が，抗てんかん薬服用患者にどのくら いの頻度ととの程度の症状を持つて出現して来る かは不明である。また，抗てんかん薬の甲状腺木 ルモンに対する影響は主として末梢での $T_{4}$ のク リアランス，異化作用に上るとされている．本例 では，脳外科に入院した時, 大量のシフェニール ヒダントインが使われ，2 2 週間後に下肢に高 度の浮腫が出現し, 検查で $\mathrm{T}_{3}, \mathrm{~T}_{4}$ が低下していた。 抗てんかん薬の服用を減量したところ， $\mathrm{T}_{3}, \mathrm{~T}_{4}$ が 正常に回復して来て（先に $\mathrm{T}_{3}$ が回復し， $\mathrm{T}_{4}$ はな゙ 低い), 浮腫が消失し、アキレス腱反射の弛緩性遅 延も正常化した。なおジフェニールヒダントイン 减量後しばらくして行なつたサイロキシン結合グ ロブリン, $\gamma \mathrm{T}_{3}$, 遊離サイロキシン・インデックス (CPBA) は正常であつた.

シフェニールヒダントイン (DPH) のTSHや TRHのTSHに対する反応については，現在まで

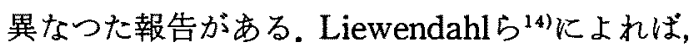
長期DPH服用患者では血清TSHやTRHに対す るTSHの反応は正常であつたとし，またT より T 4 がより抑制されると報告して打り，この報告に 従えば，本例ではDPHにより $\mathrm{T}_{3}, \mathrm{~T}_{4}$ が低下し， TSHの上昇やTRHに対しTSHの過大反応がな かつたと考えられる。

PHPはPTHの異常といらょり，PTH受容体な いし受容体以後に異常があるといわれている ${ }^{12)}$. 従つてホルモンの二次性メッセンジーである Adenyl cyclase-cAMP系を介する他のホルモン 系の異常も報告されて打り，本症に他の内分泌系 異常と乙て原発性甲状腺機能低下症 ${ }^{15)}$, TSH単独 欠損症 ${ }^{16)}$, 低プロラクチン血症, 尿崩症, ゴナドト ロピンおよびグルカゴンの異常などの合併が記載 されている。本例では， $\mathrm{T}_{4}$ が低下， $\mathrm{T}_{3}$ は正常〜軽 度低下で，TSHはTRHに正常に反応を示し検查 の結果，上述のごとく抗てんかん薬により甲状腺 
機能低下症が薏起されたものと考えられた，プロ ラクチン, LH, FSHはいずれも正常であつた。な お。，本例ではACTHの上昇があつたが，血浆コル チゾール值, $17 \mathrm{OHCS}, 17 \mathrm{KS}$ の排泄量は正常であ つた. 長期DPH服用時には, cortisol代謝異常が起 こり，尿中に6OHFの増加がみられる 本例のACTH上昇はDPHのコルチゾール代謝と 何らかの関連があると思われる。

本症をPTHの䁍器（腎・骨）火対寸る反応によ つて，Frameらは 3 型に分けた，その分類に従え ば，本例はPHP type Iに当る。また厚生省研究班 の分類でる骨反応型と診断される。本例では骨 X 線像と血清广ルカリフォスファターゼの上昇か ら，骨はPHPに反応していると考えられた。すな わち PHP I 型 (Frame) と同様にPHP II 型 (Drezner) に，惄不応・骨反応型が存在すること が示唆された。

しかし，本例の骨変化の問題は複雑である。本 例の春椎骨の病変はX線像上骨粗箖症の変化であ るが，骨粗鬆症の診断は血清Ca，P和よびalk-P. aseの変化から考光にくい.骨軟化症に骨粗錫症的 な変化が上く認められるといらから，これを考慮 すれば，骨粗鬆症も加わつていると考えられる。 次に，本例は長期にジフェニールヒダントインと フェノバルビタールを服用していたから，抗てん かん薬による骨軟化症による骨変化なのか, PHP による骨変化なのかが問題となる，全身の骨X線 像上本症にはbone cystないしbrown tumorを思 わせる骨変化はなかつた，X線像的にはcystが存 在しない場合, 骨軟化症の骨変化とPHPによる骨 変化は区別出来ない(18)といわれる。なたDrezner ら ${ }^{19}$ はPHPに拈ける低Ca血症や骨病変は活性型 Vitamin D $\left(1-25(\mathrm{OH})_{2} \mathrm{D}_{3}\right)$ の低下によるため だとして，骨に腎と同じうなPTH〜Adenyl cylase系が存在し，PTHが骨のこの系に作用する のではなく，活性Vitamin Dを介するのだと報告 した.一方, Jubizら ${ }^{20)}$ は抗てんかん薬服用患者で は, $25(\mathrm{OH}) \mathrm{D}_{3}$ は低いが, $1-25(\mathrm{OH})_{2} \mathrm{D}_{3}$ の低 下はなく，骨軟化症の原因は $1-25(\mathrm{OH})_{2} \mathrm{D}_{3}$ の障 害でなく，抗てんかん薬の腸からのCa吸収障害で
あろらとした，さらに，本症では測定しなかつた が, 24-25 $(\mathrm{OH})_{2} \mathrm{D}_{3}$ と骨の関係が明らかにされ つつある。本例では25 $(\mathrm{OH}) \mathrm{D}_{3}$ が低く，骨軟化症 の所見を示唆したが，1-25(OH $)_{2} \mathrm{D}_{3}$ る低值を示 し，骨変化が抗てんかん薬長期服用による骨軟化 症と,PHPの両者によつてひき起こされている可 能性が示唆された。

\section{おわりに}

低カルシウム，高燐血症を呈し，EllsworthHoward試験により，PHP II 型と診断した 1 例を 報告した，本例には骨X線像上著明な脊椎骨の変 化があり，この変化はPHP II 型による直接変化 $\left(1-25(\mathrm{OH})_{2} \mathrm{D}_{3}\right.$ の低值) と抗てんかん薬による 変化 (25 (OH) $\mathrm{D}_{3}$ の低下) と考光られた. $\mathrm{T}_{3}, \mathrm{~T}_{4}$ の低下，ACTHの高值がみられたが，これらの変 化もDPHによると考克られた，170HCS，17KS， 血㓡コルチゾールは正常であつた。

\section{文献}

1) Drezner M, et al: Pseudohypoparathyroidism type II : A possible defect in the reception of the cyclic AMP signal. New Engl J Med 289: 1056, 1973.

2) Baxter JD and Funder JW : Hormone receptors. New Engl J Med 301 : 1149, 1979.

3) Haussler MR and McCain TA: Basic and clinical concepts related to vitamin D metabolism and action (Second of two parts). New Engl J Med 297: 1041, 1977.

4) Farbel $Z$, et al: Defect of receptor-cyclase coupling protein in pseudohypoparathyroidism. New Engl J Med 303: 237, 1980.

5) 偽性副甲状腺機能低下症拈上び類縁疾患診断の手 引き，厚生省特定疾患ホルモン受容体異常症調查 研究班 (班長：井村裕夫), 昭和55年度總括研究事 業報告畫, p23.

6) Frame $B$, et al: Renal resistance to parathyroid hormone with osteitis fibrosa. "Pseudohypohyperparathyroidism". Amer J Med 52: 311, 1972.

7）井村裕夫：偽性副甲状腺機能低下症の診断の手引 き. 厚生省特定疾患ホルモン受容体暴常症調查研 究班(班長：井村裕夫)。昭和51年度紷括研究事業 報告書，昭和51年， p27。

8）土屋 裕，他：副甲状腺機能低下疾患の型別猃断。 ホルモンと臨床 $29: 160 ， 1981$.

9）井村裕夫，他：ホルモン受容体異常症のかが国に 
おける実態。日内分泌会誌 $56: 1031 ， 1980$.

10) Cohen ML and Donnell GN: Pseudohypoparathyroidism with hypothyroidism. J Padiatr $56: 369,1960$.

11) Gharib $\mathrm{H}$ and Munoz JM : Endocrine manifestations of diphenylhydantoin therapy. Metabolism $23: 515,1974$.

12) Yeo PPB, et al: Anticonvulsants and thyroid function. Brit Med J 1: 1581, 1978.

13) Ingbar $\mathrm{SH}$ and Woeber $\mathrm{KA}$ : The thyroid gland. Williams RH, ed, Textbook of endocrinology sixth ed, WB Saunders, Philadelphia, 1981, p117.

14) Liewendahl $\mathrm{K}$ and Majuri $\mathrm{H}$ : Thyroxine, triiodothyronine, and thyrotropin in serum during long-term diphenylhydantoin therapy. Scand J Clin Lab Invest 36: 141, 1976.

15) Mark SJ, et al: Thyroid dysfunction in pseudohypoparathyroidism. J Clin Endocrinol $33: 822,1971$.
16) Winnacker JL, et al: Pseudohypoparathy. roidism and selective deficiency of thyrotropin : An interesting association. Metabolism $16: 644$, 1967.

17) Werk EE, et al: Effect of diphenylhydantoin on cortisol metabolism in man. $\mathrm{J}$ Clin Invest $43: 1824,1964$.

18) Paul LW and Juhl JH: The essentials of roentogen interpretation third ed, Harper and Row, Hagertown, Maryland, 1972, p104.

19) Drezner MK, et al: 1,25-Dihydroxycholecalciferol deficiency: The probable cause of hypocalcemia and metabolic bone disease in pseudohypoparathyroidism. J Clin Endocrinol and Metab $42: 621,1976$.

20) Jubiz W, et al: Plasma 1,25-Dihydroxyvitamin $D$ levels in patients receiving anticonvulsant drugs. J Clin Endocrinol and Metab $44: 617,1977$. 